European Journal of Accounting, Auditing and Finance Research

Vol.8, No. 6, pp.1-14, May 2020

Published by ECRTD-UK

Print ISSN: 2053-4086(Print), Online ISSN: 2053-4094(Online)

\title{
FINANCIAL REPORTING QUALITY AND SHAREHOLDERS' WEALTH MAXIMIZATION: EVIDENCE FROM LISTED COMPANIES IN NIGERIA
}

\author{
Appolos, N. Nwaobia ${ }^{1}$ and Ademola Ajayi ${ }^{2}$ \\ 1-2 Accounting Department'Babcock University, Ilishan Remo, Ogun State, Nigeria \\ Corresponding Author: ademolaajayi77@ gmail.com
}

\begin{abstract}
A primary objective of shareholders' equity investment is the expected returns. The level of returns depends largely on the operational and managerial competences and effectiveness of the managers as reflected in reported financial statements. However, the quality of financial reporting in some cases appears to be questionable. Consequent to this, this study investigated the effect of financial reporting quality on shareholders' wealth maximization. The study population consisted of 173 listed companies on the Nigerian Stock Exchange, from which a sample of 10 companies were purposively selected based on the availability of complete and relevant data for a period of 10 years (2008-2017). Data were extracted from the published financial statements of the companies selected, while descriptive and panel data regression analyses were employed. The validity and reliability of the data were anchored on external auditors' certification of the financial statements in line with statutory requirements. The study found that Shareholders' wealth maximization was positively affected by the financial reporting quality $\left(\right.$ Adj $^{2}=0.170 ; F(2,98)$ $=41.96 ; p=0.000)$. The individual effects of Earnings persistence (EPES) and Earnings smoothness (ESM) on Shareholder's wealth maximization (SHWM) were negative and statistically insignificant $\left(\beta=-0.044 ; t_{(100)}=-0.483 ; p=0.629 ;\right.$ and $\left.\beta=-0.038 ; t_{(100)}=-0.460 ; p=0.645\right)$ respectively. The study recommended that managers should exercise high level of competence and effectiveness in managing the shareholder's equity to ensure robust returns since this is key in attracting equity investments.
\end{abstract}

KEYWORDS: Financial reporting quality, Earning smoothing, Shareholders, Earnings persistence, Managerial competence.

\section{INTRODUCTION}

Wealth maximization had always been the desire of every potential investor and shareholders of listed companies seem to be motivated to make investment decisions based on this expectation. Shareholders' wealth maximization (SHWM) is the measure of the level of profitability of the ordinary shareholders' investment and a reflection of the competencies of the managers in utilizing the available resources for value creation. It is defined by the relationship between profit after tax and the number of common shares outstanding. Basically, Shareholder's wealth maximization (SHWM) demonstrates the viability and reward ability of the company on a per share basis. According to Pandey (2010), Shareholders' wealth maximization is a profitability index, and is a valuable and widely used measuring matrix of the Shareholders' wealth maximization for a company with positive earnings. It has been considered a good measure of shareholders' wealth by many studies, for example, Asia \& Ratan, (2019) as well as Arowosegbe \& Emeni, (2014). 
European Journal of Accounting, Auditing and Finance Research

Vol.8, No. 6, pp.1-14, May 2020

Published by ECRTD-UK

Print ISSN: 2053-4086(Print), Online ISSN: 2053-4094(Online)

According to Habib and Jiang (2015), Shareholders' Wealth Maximization (SHWM) is one of the most important variables to measure the performance of a business, as investors take investment decisions based on the expectation that management would create value for the investors, stating that the accuracy of Shareholders' wealth maximization predictions is a main factor of market forecasts. Many scholars had studied Shareholder's wealth maximization (for example, Cudia \& Manaligod, 2011; Jordan, Clark \& Smith 2007; Nikolai \& Bazley, 2010). While Nikolai and Bazley (2010) studied Shareholders' wealth maximization as a helpful measure to estimate return on investment and likely associated risk taken by the company, Jordan et al. (2007) argued that there are some limitations in the use of SHWM as a measure of firm performance. Their argument is that SHWM may be used for large establishments but should not be used for small companies' analysis since it is a poor measure of companies of different sizes thereby not useful for interfirm comparison. Theoretically, Shareholders' wealth maximization is essentially a measure of an establishment's financial performance and estimated economic strength relative to size in the industry.

Prior literature had shown enough evidence that the shareholders are always at the losing end due to dishonesty and unethical practices, accounting manoeuvers with deceitful intentions and accounting fraud through the exploitation of the managers' privileged positions, negating shareholder wealth maximization goals. For example, the case of Xerox of improper accounting and deviation from accounting principles, WorldCom of leveraging of shares to raise debt for expensive acquisition, Enron and Arthur Anderson of lack of transparency and premeditated projection of healthy picture of performance, Tyco of aggressive acquisition strategies and accounting frauds, Polly Peck the case of diverting business cash flow into off-share family owned entities and BCCI banks for deceitful acts and highly leveraged financial instruments in the case of Goldman Sachs (Yahanpath, 2011) are evidences of such unethical practices and accounting maneuvers that have spelt doom for companies and their shareholders' interests.

The issue of whether there is a nexus between Financial Reporting Quality (FRQ) and Shareholders' Wealth Maximization (SHWM) using earnings per share as proxy, has been greatly debated in literature. Nevertheless, despite more than 20 years prior studies on the issue (Bamidele, Ibrahim and Omole, 2018), there has been contradictions in the results. Whereas many of these prior empirical studies have reached the conclusion that there is a positive association between financial reporting quality and SHWM (for example Adetula, Owolabi \& Onyinye, 2014; Hassan, 2015), there has also been several other studies resulting in negative association (Chao-Jung, 2015; Patro \& Gupta, 2016) and yet some reported neutral and non-significant results (for example, Duarte \& Azevedo 2015) or mixed relationships (Fariba \& Mehran, 2016; Taouab, Ahsina \& Daghi, 2014). The reason behind these contradictions could be explained by the inconsistences or vagueness in the construct of the measurement aimed at capturing financial reporting quality and earnings per share (Callan \& Thomas, 2009). Callan and Thomas (2009) posited that there is therefore need for more research concerning the nexus between financial reporting quality and earnings per share.

Moreover, the corporate scandals that led to the collapse of giant corporations such as Enron and WorldCom brought to the fore, the greater need to investigate the quality of financial reports and 
European Journal of Accounting, Auditing and Finance Research

Vol.8, No. 6, pp.1-14, May 2020

Published by ECRTD-UK

Print ISSN: 2053-4086(Print), Online ISSN: 2053-4094(Online)

heightened the demand for a more transparent governance mechanism (Hassan \& Ahmed, 2012). Relatively weak regulatory environments, weak corporate governance low information disclosure level and regulatory non-compliance are additional factors that have tended to cast doubts on the quality of financial reporting and their effect on earnings per share. Consequently this study investigated the effect of financial reporting quality on Shareholder's wealth maximization of the listed companies in Nigeria.

Relying on Agency and stakeholders theories, this study argues that shareholder wealth maximization could only be achieved when managerial efforts are geared towards reporting quality, transparent reporting and compliance with information disclosure requirements. This is the only way to reflect the underlying economic reality and substance of transactions and other events that occurred within the reporting period. More so, stakeholder' theory advocates managerial inclusiveness, as other categories of stakeholders are equally interested in the level of performance of the firm. This study made contributions to knowledge in the following areas. Firstly, from the theoretically perspective, the study aligned its theoretical underpinning to the ideology of agency and stakeholder theories' relevance and thought. From the empirical stand point, the study had established that financial reporting quality positively affects shareholders' wealth maximization, while earnings smoothing is inversely related to shareholders wealth maximization.

The rest of the study is organized in this manner: In section 2, extant literature from the perspectives of conceptual consideration, underpinning theory and empirical are reviewed. Section 3 , considered methodology and measurement of variables. In section 4, the study presented the data analysis, results and discussion of findings. The study presented the conclusion and recommendations in section 5 .

\section{EXTANT LITERATURE}

\section{Conceptual Consideration}

Financial Reporting Quality: Financial reporting is one of the means to measure and to reflect an establishment's financial and overall performance, including shareholders' wealth. Financial reporting quality is defined in terms of its relevance to users of the financial information and the extent to which such information are faithfully represented, in that they capture the economic reality of transactions and other events that took place within the reporting period. Thus, financial reporting quality pertains to the quality of information conveyed in financial reports, including relevant disclosures. Some authors(for example, Williams 2005, and Penman 2003) define financial reporting in terms of quality of earnings, that is, the degree to which reported earnings reflect economic reality. Penman (2003) submitted that high quality earnings are the earnings that contain a good indicator for future earnings, with regard to the current performance of the company. In other words, quality of earnings currently reported should be so credible that an investor could rely on it as a good predictor of future earnings. Hassan and Ahmed (2012) opined that reliable and effective information from reported financial statements motivate interested and potential investors in placing confidence in making investment decisions. Jensen (1986) on the other hand viewed financial reporting as the informativeness of financial reports about the 
European Journal of Accounting, Auditing and Finance Research

Vol.8, No. 6, pp.1-14, May 2020

Published by ECRTD-UK

Print ISSN: 2053-4086(Print), Online ISSN: 2053-4094(Online)

company's underlying economics which affects dividend policy in three categories: firstly, reporting quality can affect dividend by mitigating the free cash flow problem; scondlyit recognizes that managers have incentives to understate dividends and thirdly managers can "invest the cash flow in value-destroying projects for private benefits" (Jensen, 1986, p23).

Wealth Maximization: The Shareholder's wealth maximization measures the amount of profit for the period available to the owners as the residual returns resulting from the operational activities during the period under consideration. Studies had measured the performance of expected returns due to the equity providers of fund using Shareholder's wealth maximization (Kapellas \& Siougle, 2017). Liu and Sun (2017) opined that Shareholder's wealth maximization is a suitable performance evaluation technique to ascertain the productiveness of the managers saddled with the responsibility of piloting the affairs of the company and a good parameter to measure the amount of return on ordinary shareholder's investment based on current period's performance (Fayed \& Dubey, 2016).

Earnings Smoothing: The concept of earnings smoothing had been viewed from different angles. Some studies had presented earnings smoothing as the application of accounting policies to present or to structure particular transactions in such a manner that the financial statements will portray picture of financial health that is in line with what the directors would like users to see rather than the true position of the financial performance and the underlying realities on ground (Idekwulim, 2014). Yet, other studies argued that there are some genuine and natural earnings smoothing occasioned by managerial competence and optimal utilization of the company resources. Bao and Bao (2004), in consonance with Albrecht and Richardson (1990, p89) "postulated that there are two types of income smoothing namely, a natural smoothing as a result of genuine result from income generating process devoid of manipulations by the managers, and the other is either intentional smoothing or real smoothing."

Earnings persistence: When earnings are persistent, devoid of earnings management, it could be used as a good predictor by analysts and shareholders for the future performance of companies. One of the weaknesses of earnings persistence is the likelihood that it could be manipulated by the company management (Prawat, 2011). There are factors which have been adjudged as influencing financial reporting quality of companies, among which include non-discretionary accruals, and persistence of earnings devoid of manipulations (Klein, 2002). The likely management opportunistic tendencies which could affect the quality of reporting may as well undermine effective earnings and financial reporting quality (Liao \& Hsu, 2013).

\section{THEORETICAL UNDERPINNING}

The underpinning theories for this study are the agency theory and stakeholders' theory. The concept of agency theory was postulated by Berle and Means (1932) who argued that the rise of large corporations resulted in increased dilution of equity ownership and the separation of ownership and control. This situation offers room for opportunistic behaviours by managers (the agents) to subjugate the interest of shareholders to their personal interests (Jensen \& Runback, 1983). Agency theory according to Jenson and Meckling (1976), tends to address the conflicts that 
European Journal of Accounting, Auditing and Finance Research

Vol.8, No. 6, pp.1-14, May 2020

Published by ECRTD-UK

Print ISSN: 2053-4086(Print), Online ISSN: 2053-4094(Online)

exist between owners of companies and their managers. The theory according to Alves (2011) argued that the board of directors is saddled with the responsibility of monitoring the managers' action so that the stakeholders are not deceived in the presented accounting information in the financial statements.

However, the stakeholders' theory looks beyond the nexus between shareholders and managers to take into account other interest groups in the firm. Sanda, Mikailu and Garba documented that other interest parties of stakeholders like suppliers, employees, host communities, and the government are all relevant in the wellbeing of the company, as its favouable and unfavourable fortunes equally affects them. The stakeholder's theory therefore suggests that every firm should endeavor to create value for all the stakeholders and not only shareholders wealth maximization. Agency theory and stakeholders theory are relevant to the study because, in agency theory the shareholders demand the periodical evaluation of the actions of the managers to get the assurance that they effectively and efficiently utilize entrusted resources for the purpose of shareholders' wealth creation, while the stakeholder theory proposes some level of inclusiveness which extends managerial concern beyond the interest of shareholders wealth maximization to include other stakeholders who are legitimately entitled to both the wealth created by a firm and quality financial information.

\section{Empirical Review}

Rajpogal and Venkatachalam (2011) examined the variance of stock returns and variables affecting financial reporting quality. The study found that deterioration in financial reporting quality was associated with volatility of stock returns over the past 40 years. Chan-Jane, Tawei and Chao-Jung (2015) reporting on the relationship between financial reporting quality and investment in family firms and non-family firms in China, submitted that family owned firms are more likely to under-invest than non-family owned firms because they want to protect their socio emotional wealth. The study also found that financial reporting quality is more negatively related with family owned companies' under- investment behavior.

Examining the effect of accounting conservatism on investment, Abd-Elnaby and Aref (2019) affirmed the relevance of accounting conservatism in improving the quality of financial reporting information in Egypt. Noor (2014) examined the impact of economic fundamentals on stock returns of 10 listed companies in Australia. The study used accounting based financial measures and market based financial measures of 10 listed companies for a period of 10 years from 20012010. The study revealed that market based financial performance measures can better explain the stock price variances than the accounting based financial measures. The market based variables exerted a significant positive impact on the firm performance.

Shehu and Ahmad (2013) investigated the impact of firm size, leverage, profitability and liquidity on financial reporting quality and also the performance level of the quoted companies in Nigeria for the period covered. The study concluded that financial reporting quality was positively affected by the variables of firm size, leverage, profitability and liquidity of the selected quoted companies in Nigeria. 
European Journal of Accounting, Auditing and Finance Research

Vol.8, No. 6, pp.1-14, May 2020

Published by ECRTD-UK

Print ISSN: 2053-4086(Print), Online ISSN: 2053-4094(Online)

In the work on accounting conservatism, bank lending and firm investment from China stimulus package companies, Pan (2017) concluded that companies that reported conservatism accounting in their financial statements had better investment decisions. It also found that accounting conservatism assisted in monitoring managerial decisions on capital allocation to improve transparent reporting, investment efficiency and facilitated bank loans resulting in reduced underinvestment. Hong, Kim and Lobo (2017) examined whether financial reporting conservatism mitigate underwriting. The study found that the quality of financial reporting among the firms revealed high level of transparency and that conservatism reduced adverse selection problem and also helped in external financing.

Olandipupo and Okafor (2011) studied control of shareholders' wealth maximization in Nigeria. The study focused on parties controlling shareholders' wealth and ways it affects the company's performance, using data collected from selected 6 companies listed in the Nigerian Stock Exchange from the food/tobacco subsector. The study found that firm shareholders' wealth impacted financial reporting quality. Also that firm size, retained earnings collectively had statistical positive relationship with shareholders' wealth. However, the study revealed that turnover and retained earnings had a stronger effect on shareholders' wealth than dividend payout.

From Kenya, Kariuki and Jagongo (2013) investigated the investors' general perception of the financial reporting quality. The study sort to establish the investors' view of the quality of financial reporting in Kenya using a survey research design. The study revealed that there exists a positive relationship between financial reporting quality and the performance of the companies Meanwhile, Nwaobia, Kwarbai, Jayeoba and Ajibade (2016) examined financial reporting quality on investors' decision. The study used 10 selected manufacturing companies listed on the floor of the Nigerian Stock Exchange, covering a period of 5 years 2010-2014. The study found that there is a positive relationship between investors' decision and financial reporting quality of the selected listed companies in Nigeria. Finally, Farnukh, Irshad, Khakwani, Ishaque and Anasari (2017) investigated the effect of dividend policy on shareholders wealth and firma performance. The study employed dividend yield and dividend per share as the explanatory variables and shareholders was measured using earnings per share and share price, while return on equity was used to measure performance. The study found that dividend policy had a positive significant effect on shareholders wealth. The study recommended stable, effective and targeted oriented policies that could improve shareholders fund.

Similarly, Haruna and Kighir (2018) examined the effect of IFRS adoption on shareholders wealth of deposit money banks in Nigeria. The study employed longitudinal research design using data collected from the published financial statements of deposit money banks listed on the Nigerian Stock Excahnge for a period of 8 years (2008-2015). Multivariate analysis of variance (MANOVA), Multivariate analysis of covariance (MANCOVA), AND MULTIPLE Regression models were for the data analysis. Dividend per share, market value per share, earnings per share and return on equity were used to measure shareholders wealth, while pre and post treatments serves as a categorical variable and inflation as a continuous control variable. The study found that financial reporting pre and post had a positive significant effect on shareholders wealth. On the basis of the results from these empirical studies, this study hypothesized as follows: 
European Journal of Accounting, Auditing and Finance Research

Vol.8, No. 6, pp.1-14, May 2020

Published by ECRTD-UK

Print ISSN: 2053-4086(Print), Online ISSN: 2053-4094(Online)

Ho: Financial reporting quality has no significant impact on the Shareholder's wealth maximization of listed companies in Nigeria.

\section{METHODOLOGY}

This study investigated the effect of financial reporting quality on Shareholder's wealth maximization. The study population consisted of 173 listed companies on the Nigerian Stock Exchange, from which a sample of 10 companies were purposively selected for a period of 10 years (2008-2017). The study covered 100 firm-year observations for the period under consideration. Data were extracted from the published financial statements of the companies selected, and analysed using descriptive and regression statistics. The validity and reliability of the data were based on the certification of these financial statements by external auditors in line with statutory requirements. Shareholder's wealth maximization was proxied with EPS and financial reporting quality with earnings persistence and earnings smoothing.

\section{Measurement of Variables}

Shareholder's wealth maximization is the measure of returns available to the shareholders as the residual income due to shareholders. Shareholder's wealth maximization relates the earnings generated by the business and available to ordinary shareholders to the number of ordinary shares ranking for dividend during the period. The study adopts Gaio and Raposo (2011) model and compute the variable as follows:

SHWM = Net Profit available for equity holders

Equity shares in issues and ranking for dividend

Financial reporting quality is measured using earnings persistence and earnings smoothing.

Earnings Persistence: Earnings $=\phi_{0}+\phi_{\mathrm{it}}$ Income $_{\mathrm{it}-1}+\mu_{\mathrm{it}}$

Where:

Income $_{i t}=$ Net income before extraordinary items of firm ${ }_{i}$ in year $t$

Income $_{i t-1}=$ net income before extraordinary items of firm $i$ in year $t-1$

$\phi_{0 i}=$ constant (intercept) coefficient

$\phi_{1 i}=$ the non-constant (slope) coefficient

Earnings Smoothing: The earnings smoothness is measured as the percentage of the firm-level standard deviation of earnings and the standard deviation of the operating cash flow as used in Gaio \& Raposo (2011). Thus,

ESMS = The Std. Deviation of Net income before extraordinary items

Cash flow it lagged by Total Assets it $^{-1}$

Where Net income before extraordinary income $=$ the firm i's net income before extraordinary items of firm $i$ in year $t$, Cash flow is cash flow from operation of firm $i$ in year $t$; Total assets is total assets of firm $i$ in year $t-t$ 
European Journal of Accounting, Auditing and Finance Research

Vol.8, No. 6, pp.1-14, May 2020

Published by ECRTD-UK

Print ISSN: 2053-4086(Print), Online ISSN: 2053-4094(Online)

\section{Model Specification'}

$\mathrm{Y}_{\mathrm{it}}=\beta_{0}+\beta_{1} \mathrm{X}_{\mathrm{it}}+\varepsilon_{\mathrm{it}}$

Where

$\mathrm{Y}=$ Dependent variable: Shareholder's wealth maximization

$\mathrm{X}=$ Independent variable: Financial Reporting Quality

While

$\mathrm{Y}=\mathrm{y}_{1}$ and $\mathrm{X}=\left(\mathrm{x}_{1}, \mathrm{x}_{2}\right)$

Thus,

$\mathrm{SHWM}=f(\mathrm{EPES}, \mathrm{ESM})$

Model of the Study

$\mathrm{SHWM}_{\mathrm{it}}=\beta_{0}+\beta_{1} \mathrm{EPES}_{\mathrm{it}}+\beta_{2} \mathrm{ESM}_{\mathrm{it}}+\varepsilon_{\mathrm{it}}$

Where:

SHWM $=$ Shareholder's wealth maximization

EPES $=$ Earnings persistence

$\mathrm{ESM}=$ Earnings Smoothing

$\beta_{0}=$ regression intercept which is constant, $\beta_{1}, \beta_{2}=$ the coefficient of the explanatory variables and $\varepsilon$ is the error term of the model, $i=$ cross-sectional variable, $t=$ time series variable

\section{A priori Expectation}

This study expected that a positive relationship between financial reporting quality and and shareholders' wealth maximization. That is, financial reporting quality would positively affect return on shareholder's equity. Hence, the a priori expectation is represented thus: $\beta_{1}, \beta_{2}>0$.

Model Selection (Hausman and LM Specification) Tests for Effect of Financial Reporting Quality Indicators on Shareholder's wealth maximization

Table 1: Hausman and LM Specification Tests for Shareholder's wealth maximization and Financial Reporting Quality Indicators.

\begin{tabular}{l|lll}
\hline Test & Chi2 & Prob. & Remark \\
\hline Hausman & 1.10 & 0.776 & NS \\
Lagrangian multiplier (LM) & 346.89 & 0.000 & S \\
\hline
\end{tabular}

Source: Authors Computation, 2019 using STATA 13. Note: $S=$ Significant and NS $=$ Not Significant. $* * * p<0.01, * * p<0.05, * p<0.1$

The Hausman's test conducted in this subsection basically tests whether the unique errors (term errors) are correlated with the regressors. A significance of the test implies fixed effect; otherwise random effect model. However, Breusch-Pagan Langragian multiplier (LM) test helps to decide between a random effect and OLS regressions models. The null hypothesis in the LM test is that there is no significant difference across units. A significance of the test implies random effect model (REM); otherwise OLS model. Overall, the results of the tests in Table 1 show that the 
Print ISSN: 2053-4086(Print), Online ISSN: 2053-4094(Online)

Hausman and Lagrangian multiplier $(\mathrm{LM})$ values are $1.10(\mathrm{p}=0.776)$ and $346.89(\mathrm{p}=0.000)$ respectively. These show preference for the random effect model (RE). Thus, the study adopts the result of the Random Effect model as the lead model and therefore Random Effect is interpreted.

\section{DATA ANALYSIS, RESULTS AND DISCUSSIONS}

2.3.4 Normality and Homoscedasticity Test for Shareholder's wealth maximization and Financial Reporting Quality Indicators.

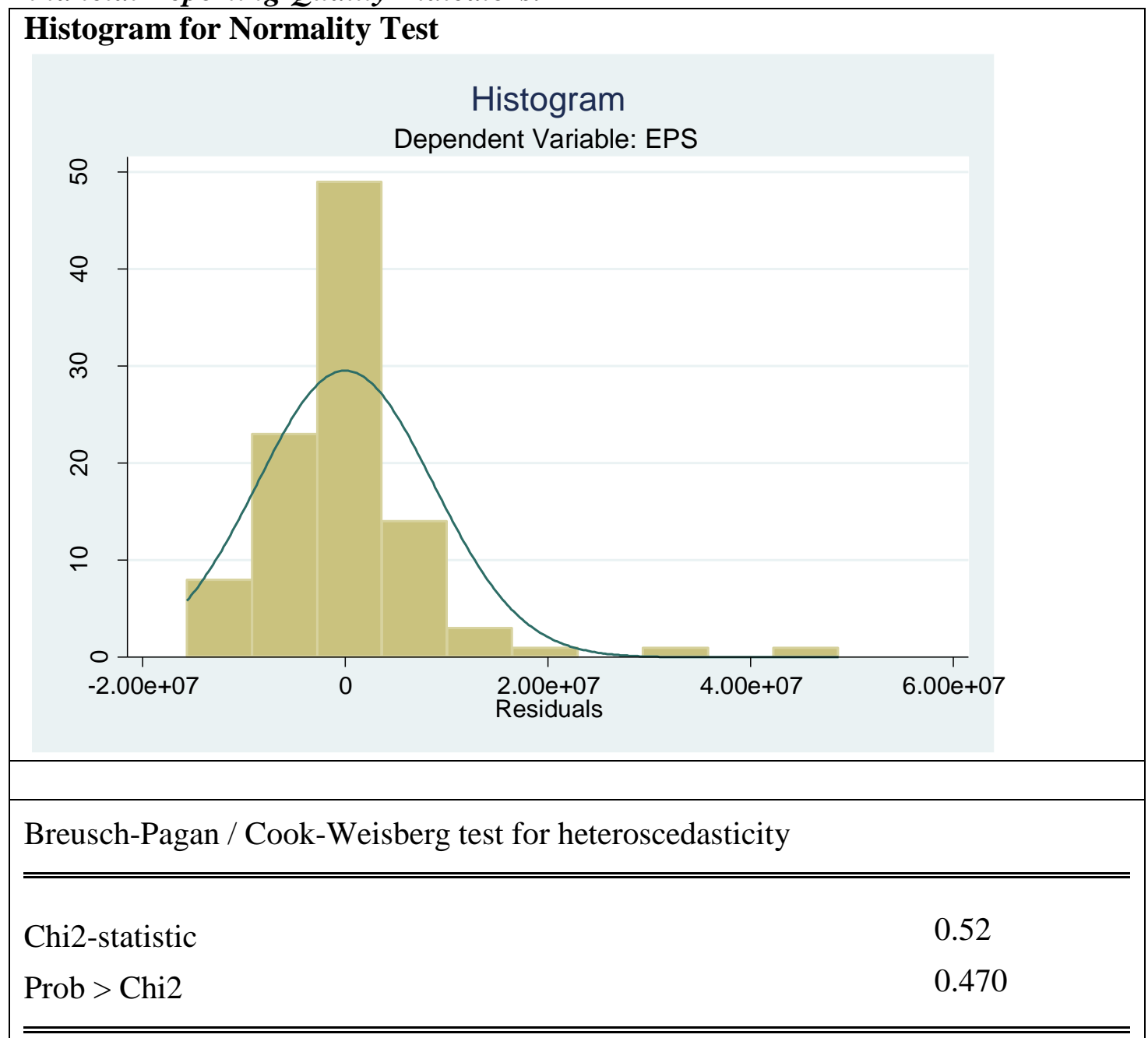

Source: Authors Computation, 2019 using STATA 13.

Fig. 1 Normality and Homoscedasticity Tests

Figure 1 presents the histogram and scatterplot used for testing the regression assumptions of normality and homoscedasticity respectively. The residual of the model appears to meet the assumptions of normality since the shape of histogram is much closer to the shape of the normal curve. However, the Breusch-Pagan / Cook-Weisberg test for heteroscedasticity result with the 
European Journal of Accounting, Auditing and Finance Research

Vol.8, No. 6, pp.1-14, May 2020

Published by ECRTD-UK

Print ISSN: 2053-4086(Print), Online ISSN: 2053-4094(Online)

insignificant probability value $(\mathrm{P}>0.01)$ indicates that the model does not suffer from heteroscedasticity problem

Effect of Financial Reporting Quality Indicators on Shareholder's wealth maximization Table 2: Regression Estimate for Research Model

\begin{tabular}{|l|l|l|l|l|}
\hline \multirow{2}{*}{ Variable } & \multicolumn{4}{|l|}{ Dependent Variable: SHWM } \\
\cline { 2 - 5 } & Coefficient & Std. Error & T & Prob. \\
\hline Constant & 16.793 & 0.725 & 23.165 & 0.000 \\
\hline EPES & -0.044 & 0.091 & -0.483 & 0.629 \\
\hline ESM & -0.038 & 0.083 & -0.460 & 0.645 \\
\hline R-squared & 0.195 & & & \\
\hline Adj. R-squared & 0.170 & & \\
\hline F-Stat. & 41.96 & & \\
\hline Prob. (F-Stat) & 0.000 & \multicolumn{4}{|l|}{} \\
\hline Observations & 100 & & \\
\hline
\end{tabular}

Source: Authors Computation, 2019 using STATA 13.

Note: SHWM = Shareholder's wealth maximization; EPES = Earnings Persistence and ESM = Earnings Smoothness.

The financial reporting quality indicators were computed using a 4-year rolling window.

Model Result: SHWM $=16.793-0.44 \mathrm{EPES}-0.038 \mathrm{ESM}$

In Table 2, the estimated coefficients indicate that earnings persistence (EPES) and earnings smoothness $(\mathrm{ESM})$ are all negatively signed $\left(\beta_{1}=-0.044 ; \beta_{2}=-0.038\right)<0$. These are not in consonance with a priori expectations. Also as indicated in Table 2 the selected random effect of $F$-Stat. of $41.96(P$-value $=0.000)$ indicate that the Financial Reporting Quality indicators are jointly statistically significant in explaining variations in Shareholder's wealth maximization (SHWM). Also, the adjusted coefficient of determination (Adj. $\mathrm{R}^{2}$ ) value of 0.17 indicates that the explanatory variables jointly explain about $17 \%$ of variations in SHWM. These further confirm the fitness of the Random effect model.

Decision: From the results in Table 2, it is found that the relationships between Earnings persistence (EPES), Earnings Smoothness (ESM) and Shareholder's Wealth Maximization (SHWM) are negative and statistically insignificant $\left(\beta_{1}=-0.044 ; p=0.629\right.$ and $\beta_{2}=-0.038 p=$ $0.645)$ respectively. However with the joint result of the model: $\left(A d j R^{2}=0.170 ; F-S t a t .=41.96\right.$; $p=0.000$ ), there is statistical evidence to reject the null hypothesis. Therefore, the study accepts the alternative hypothesis that financial reporting quality has significant impact on the Shareholders' wealth maximization of the listed companies in Nigeria. 
European Journal of Accounting, Auditing and Finance Research

Vol.8, No. 6, pp.1-14, May 2020

Published by ECRTD-UK

Print ISSN: 2053-4086(Print), Online ISSN: 2053-4094(Online)

\section{DISCUSSIONS}

The inference from the result shows that the coefficient of Earnings Persistence (EPES) is negatively but insignificantly related to Shareholder's wealth maximization (SHWM) $\left(\beta_{1}=\right.$ $0.044 ; p=0.629$ ) within the 5\% level of significance. This implies that Earnings Persistence (EPES) does not have significant relationship with Shareholder's wealth maximization (SHWM). Also, Earnings Smoothness (ESM) is insignificantly related to Shareholder's wealth maximization $(\mathrm{SHWM})\left(\beta_{1}=-0.038 ; p=0.645\right)$ of the listed firms. This suggests that earnings smoothness (ESM) is not a determinant of Shareholder's wealth maximization (SHWM) of the selected listed firms during the period of this study just like earnings persistence (EPES).

The outcome of financial reporting quality having a negative significant relationship with Shareholder's wealth maximization is consistent with the study of Chan-Jane, Tawei and ChaoJung (2015), who found a negative relationship with financial reporting quality with firm's underinvestment in China. However, on the contrary, our findings are inconsistent with some studies who found positive significant effects (Adabenege, Kutigi \& Mohammed, 2015; Farnukh, Irshad, Khakwani \& Ansani, 2017; Haruna, Kighir, 2018; Galani, Malgwi, Idriss, 2015). For instance, Haruna and Kighir (2018) who examined the effect of IFRS adoption on shareholders wealth of deposit money banks in Nigeria, found that financial reporting pre and post had a positive significant effect on shareholders wealth, while Farnukh, Irshad, Khakwani, Ishaque and Anasari (2017) investigated the effect of financial reporting and dividend policy on shareholders wealth and firm performance, the study found that dividend policy had a positive significant effect on shareholders wealth.

\section{CONCLUSION AND RECOMMENDATIONS}

This study investigated the effect of financial reporting quality on Shareholder's wealth maximization. Resulting from the analysis, the study revealed that financial reporting quality indicators jointly had a positive significant effect on Shareholders' wealth maximization. However, the isolated effects of the sub variables of FRQ on SHWM were mixed. The study recommended that managers should exercise high level of competence and effectiveness in managing the shareholders' equity to ensure robust returns, since shareholders are mainly interested on wealth maximization. Therefore, a critical strategic planning, transparent financial reporting and optimal resources management are imperative in ensuring expected value creation and robust returns to the shareholders and other stakeholders.

\section{References}

Abd-Elnaby, H., \& Aref, O. (2019). The effect of accounting conservatism on investment efficiency and debt financing: Evidence from Egyptian listed companies. International Journal of Accounting and Financial Reporting, 9(2), 116-144.

Adabenege, O., Kutigi, U. M., \& Mohammed, A. (2015). International financial reporting standards and earnings management behaviour of listed deposit money banks in Nigeria. European Journal of Business and Management, 7(18), 2222-2839. 
European Journal of Accounting, Auditing and Finance Research

Vol.8, No. 6, pp.1-14, May 2020

Published by ECRTD-UK

Print ISSN: 2053-4086(Print), Online ISSN: 2053-4094(Online)

Adetula, D. T., Owolabi, F. \& Onyinye, O. I. (2014). International financial reporting standard for SMEs adoption process in Nigeria. European Journal of Accounting, Auditing and Financial Research, 2(4), 33-38.

Albrecht, W., \& Richardson, F. (1990). Income smoothing by economy sector. Journal of Business Finance \& Accounting, 17(5), 713-730.

Arowosegbe, A., \& Emeni, F. (2014). Shareholders' wealth and debt-equity mix of quoted companies in Nigeria. International Journal of Finance Research, 5(1), 98-125.

Asia, K., \& Ratan, G. (2019). Corporate governance practices and non-performing loans of banking sector of Bangladesh: A panel data analysis. International Journal of Accounting and Financial Reporting, 9(2), 12-28.

Bamidele M., Ibrahim, J. \& Omole, I. (2018). Financial reporting quality and its effect on investment decisions by Nigerian deposit money banks. European Journal of Accounting, Auditing and Finance Research, 6(4), 23-34.

Bao, B., \& Bao, D. (2004). Income smoothing, earnings quality and firm valuation, Journal of Business, Finance \&Accounting, 31(9) \& (10), 306-686.

Bawa, S.., \& Kaur, P. (2013). Impact of dividend policy on shareholders' wealth: An empirical analysis of Indian information technology sector. Asia Pacific Finance and Accounting Review, 1(3), $17-24$.

Callan, S. J. \& Thomas, J. M. (2009). Corporate financial performance and corporate social performance: An update and reinvestigation. Corporate Social Responsibility and

Environmental Management, 16(2), 61-78.

Chan-Jane, L., Tawei, W., \& Chae-Jung, P. (2015). Financial reporting quality and investment. Journal of Accounting and Marketing, 1(2), 452-461.

Cudia, C. P., \& Manaligod, G. T. (2011). Earnings per share (EPS) as a measure of intercompany performance: Philippine evidence. Journal of International Business Research, 10(1), 7990.

Devaki, S., \& Kamalaveni, D. (2012). Shareholding patterns and dividend payout: An empirical analysis in Indian corporate hotels. International Journal of Multidisciplinary Research, 2(1), 49-63.

Dixon-Fowler, H., Slater, D. J., Johnson, J. L., Ellstrand, A. E., Romi, A. M. (2013). Does it pay to be green?. A meta-analysis of moderators of the CEP-CFP relationship. Journal of Business and Ethics, 112(4), 353-366.

Duarte, A. M. P. \& Azevedo, G. M. C. (2015). International financial reporting standard adoption accounting quality: A review. Journal of Business and Economic Policy, 2(2), 104-123.

Fariba, S., \& Mehran, A. (2016). Effect of financial reporting quality and investmentopportunities and dividend based on decision making of insurance companies in Iran.Caspain Sea Journal 1(10), 133-137.

Farrukh, K., Irshad, S., Khakwani, M. S., Ishaque, S., \& Ansari, N. Y. (2017). Impact of dividend policy on shareholders wealth and firm performance in PakistanCogent Business \& Management (2017), 4: 1408208

Fayed, A.M. \& Dubey, S. (2016). An empirical study of impact of EVA momentum on the 
European Journal of Accounting, Auditing and Finance Research

Vol.8, No. 6, pp.1-14, May 2020

Published by ECRTD-UK

Print ISSN: 2053-4086(Print), Online ISSN: 2053-4094(Online)

shareholders value creation as compared to traditional financial performance measures-with special reference to the UAE. International Journal of Economics and Finance 8(5), 2341.

Gaio, C., \& Raposo, C. (2011). Earnings quality and firm valuation: International evidence. Accounting and Finance, 51(2), 467-499

Gulani, M.G., Malgwi, A.A. \& Idriss, A.A. (2015). Effects of the adoption of international financial reporting standards (IFRS) on performance measurement ratios of banks in Nigeria. The Sahel Analyst: Journal of Management Sciences, 13(1), 1-9.

Habib, A., \& Jiang, H. (2015). Corporate governance and financial reporting quality in China: A survey of recent evidence. Journal of International Accounting, Auditing and Taxation, 24, $29-45$.

Hahn, T., \& Figge, F. (2011). Beyond the bounded instrumentality in current corporate sustainability research: Toward an inclusive notion of profitability. Journal of Business Ethics, 104(2), 325-345.

Hassan, O. M. (2015). Effects of banks consolidation on economic growth in Nigeria (2004-

2015). Journal of Emerging Trends in Economics and Management Sciences, 7(3), 184-196.

Hassan, S. U; \& Ahmed, A. (2012). Corporate governance, earnings management and financial performance: A case of Nigerian manufacturing firms. American International Journal of Contemporary Research, 2(7), 69-78.

Hong, H., Kim, Y., \& Lobo, G. (2017). Does financial reporting conservatism mitigate underinvestment?. Journal of Accounting, Auditing and Finance, 48(3), 360-385.

Idekwulim, C. (2014). Teach yourself group accounting. Piccas Global Concept, ( $1^{\text {st }}$ Ed). Yaba Lagos Nigeria.

Jensen, M. (1986). Agency costs of free cash flow, corporate finance, and takeovers. The American Economic Review 76 (2), 323-329.

Jordan, C., Clark, S., \& Smith, W. (2007). Should earnings per share (EPS) be taught as a means of comparing intercompany performance? The Journal of Education for Business, 82(6), 343-348.

Kapellas, K., \& Siougle, G. (2017). Financial reporting practices and investment decisions.A review of literature. Industrial Engineering and Management (6) 4(1), 1-9.

Kariuki, G., \& Jagongo, A. (2013). Investor's perception on financial reporting quality in Kenya. International Journal of Humanities and Social Sciences, 3(21), 24-29.

Klein, A., (2002). Audit committee, board of director characteristics, and earnings management. Journal of accounting and economics, 33(3).375-400.

Liao, C., \& Hsu, A., (2013). Common membership and effective corporate governance: Evidence from audit and compensation committees. Corporate governance: An International Review, 21(1).79-92.

Liu, G., \& Sun, J. (2017). Did the mandatory adoption of IFRS affect the earnings quality of Canadian firms? Accounting Perspectives 14(3), 250-275.

Maleya, O., \& Willy, M. (2013). Factors affecting the financial performance of listed companies at the nairobi securities exchange in Kenya. Research Journal of Finance and Accounting, 4(15), 1-8.

Nikolai, L., \& Bazley, J. (2010). Intermediate accounting mason: South-Western Cengage

Learning. 
European Journal of Accounting, Auditing and Finance Research

Vol.8, No. 6, pp.1-14, May 2020

Published by ECRTD-UK

Print ISSN: 2053-4086(Print), Online ISSN: 2053-4094(Online)

Noor, M. (2014). Stock returns and fundamentals in the Australian Market. Asian Journal of Finace \& Accounting, 6(1), 82-103.

Nwaobia, A., Kwarbai, J., Jayeoba, O., \& Ajibade, A. (2016). Financial reporting quality on investors' decisions. International Journal of Economics and Financial

Research. 2 (70), 140-147.

Olandipupo, A., \& Okafor, C. (2011). Control of share wealth maximization in Nigeria. Journal of Business System Governance and Ethics, 6(1), 19-24.

Pan, X. (2017). Accounting conservatism, bank lending and firm investment: Evidence from a Quasi-experiment of China's Stimulus Package. Pacific-Basin Finance Journal, 44(3), 6479.

Pandey, I. (2010). Financial Management, $\left(10^{\text {th }}\right.$ Ed), New Delhi, VIKAS Publishing House PVT Ltd.

Patro, A., \& Gupta, V. K. (2016) Impact of IFRS on stock price synchronicity for Asian markets. Journal of Contemporary Management Research, 12(1), 61-88.

Penman, S. H. (2003). The quality of financial statements: Perspectives from the recent stock market bubble. Accounting Horizons 17, 77 - 96.

Prawat, B. (2011). Earnings persistence, value relevance, and earnings timeliness: The Case of Thailand. (Doctoral thesis), department of Accounting and Finance: Durham business school, University of Durham. http://etheses.dur.ac.uk/1378/. Accessed 22/05/2017

Rajgopal, S., \& Venkatachalam, M. (2011). Financial reporting quality and idiosyncratic return volatility. Journal of Accounting and Economics, 51(1-2), 1-20.

Said, A. (2012). Comparing the change in efficiency of the Western and Islamic banking systems. Journal of Money, Investment and Banking, 8(2), 145-288.

Shank, T. M. P., \& Shockey, B. M. B. A. (2016). Investment strategies when selecting sustainable firms. Finance Services Review, 25(2).199-214.

Sathye, M. (2001). X-efficiency in Australian banking: An empirical investigation. Journal of Banking and Finance, 25(2), 613-630.

Shehu, U., \& Ahmad, B. (2013). Firms characteristics and financial reporting quality. International Journal of Accounting, banking and Management, 1(6), 47-63.

Taouab, O., Ahsina, K. \& Daghri, T. (2014). An empirical investigation of adopting IFRS accounting standards: Evidence from Morocco. Research Journal of Finance and Accounting, 5 (14), 1-5.

Zerbe, R. (2001). Economic efficiency in law and economics. $\left(2^{\text {nd }}\right.$ Ed) Cheltenham, UK: Edward Elgar Publishing. 